\title{
Participatory networks for large-scale monitoring of large carnivores: pumas and jaguars of the Upper Paraná Atlantic Forest
}

\author{
Carlos De Angelo, Agustín Paviolo, Daniela Rode, Laury Cullen Jr \\ Denis Sana, Kaue Cachuba Abreu, Marina Xavier da Silva \\ Anne-Sophie Bertrand, Taiana HaA g, Fernando Lima \\ Alcides Ricieri Rinaldi, Sixto Fernández, Fredy Ramírez, Myriam Velázquez \\ Cristian Corio, Esteban Hasson and Mario S. Di Bitetti
}

\begin{abstract}
Most large carnivores are secretive and threatened, and these characteristics pose problems for research on, and monitoring of, these species across extensive areas. Participatory monitoring, however, can be a useful tool for obtaining long-term data across large areas. Pumas Puma concolor and jaguars Panthera onca are the largest predators in the threatened Upper Paraná Atlantic Forest. To survey the presence of these two species we established a participatory network of volunteers and a partnership with researchers in the three countries that share the Upper Paraná Atlantic Forest (Argentina, Brazil and Paraguay). We trained participants in simple methods of collecting faeces and track imprints of large felids. Between
\end{abstract}

Carlos De Angelo (Corresponding author), Agustín Paviolo and Mario S. Di Bitetti National Research Council, Instituto de Biología Subtropical, Facultad de Ciencias Forestales, Universidad Nacional de Misiones, Puerto Iguazú, Argentina, and Asociación Civil Centro de Investigaciones del Bosque Atlántico, Yapeyú 23, CP 3370, Puerto Iguazú, Misiones, Argentina. E-mail biocda@gmail.com

Daniela Rode Fundación Vida Silvestre Argentina, Puerto Iguazú, Misiones, Argentina

Laury Cullen JR and Fernando Lima Instituto de Pesquisas Ecológicas, Teodoro Sampaio, Brazil

Denis SAnA, Instituto Pró-Carnívoros, Atibaia, Brazil

Kaue Cachuba Abreu Laboratorio de Biogeográfia da Universidade Federal do Paraná, Goiás, Brazil

Marina Xavier Da Silva Instituto Chico Mendes de Conservação da Biodiversidade, Foz do Iguaçu, Brazil

ANNE-Sophie Bertrand Rede Verde Conservation Network, Foz do Iguaçu, Brazil

Taiana HaAg Programa de Pós-Graduação em Genética e Biologia Molecular, Universidade Federal do Rio Grande do Sul, Porto Alegre, Brazil, and Laboratório de Biologia Genômica e Molecular, Faculdade de Biociências, Pontifícia Universidade Católica do Rio Grande do Sul, Porto Alegre, Brazil

Alcides Ricieri Rinaldi Laboratório de Biodiversidade, Conservação e Ecologia de Animais Silvestres, Universidade Federal do Paraná, Foz do Iguaçu, Brazil

Sixto Fernández, Fredy Ramírez and Myriam Velázquez Fundación Moisés Bertoni, Asunción, Paraguay

Cristian Corio and Esteban Hasson Laboratorio de Evolución, Facultad de Ciencias Exactas y Naturales, Universidad de Buenos Aires, Buenos Aires, Argentina

Received 22 March 2010. Revision requested 17 May 2010.

Accepted 1 July 2010. First published online 31 May 2011.
2002 and $2008>100$ volunteers helped with monitoring, obtaining 1,633 records identified as pumas or jaguars across c. $92,890 \mathrm{~km}^{2}$. We confirmed jaguar presence in a large section of the Misiones Green Corridor in Argentina and in the largest protected areas of Brazil and Paraguay. Pumas exhibited a wider distribution, being recorded throughout Misiones province in Argentina and in some areas of Brazil and Paraguay where jaguars were not detected. Both species, and especially jaguars, were detected mainly in the few remaining medium and large forest fragments in this Forest. Although these carnivores are often in conflict with local people, their charisma and cultural significance makes them flagship species that motivated the participation of volunteers and institutions. Participatory monitoring allowed coverage of a vast area at relatively low cost whilst enhancing collaborative management policies among people and institutions from three countries.

Keywords Atlantic Forest, distribution, flagship species, habitat loss, jaguar, large carnivore, participatory monitoring, puma

This paper contains supplementary material that can be found online at http://journals.cambridge.org

\section{Introduction}

Tost species of large carnivores are threatened as 1 a result of their large territorial requirements, their naturally low densities and direct persecution by humans (Noss et al., 1996; Woodroffe \& Ginsberg, 1998). Knowledge of the presence of carnivores in human-dominated landscapes constitutes the basis for determining the conservation status of these species (Karanth \& Nichols, 2002; Sanderson et al., 2002). However, their secretive behaviour and low densities make research on, and monitoring of, large carnivores difficult (Karanth \& Chellam, 2009). Indirect evidence of animal presence (e.g. tracks and scats) is a valuable resource for surveying the distribution of secretive species (Wemmer et al., 1996; Karanth \& Nichols, 2002), and sign and questionnaire surveys are commonly used to determine the presence of large carnivores 
(McNab \& Polisar, 2002; Altrichter et al., 2006; Carroll \& Miquelle, 2006). However, limited funds and personnel often make it difficult to obtain this type of data across extensive areas and over long periods of time (Karanth \& Nichols, 2002; Danielsen et al., 2005), and it is even more challenging when the search involves different countries with different cultures and languages.

Locally-based participatory monitoring programmes have demonstrated potential for surveying large areas and are particularly valuable in developing countries where the involvement of local volunteers may prompt awareness and management interventions (Danielsen et al., 2003, 2007). In spite of relatively low cost and the possibility of covering large areas, participatory monitoring networks require tools for motivating the volunteers and maintaining their interest (Bell et al., 2008). In developing countries, where resources are often limited and the culture of volunteering is not necessarily common or organized, simple, inexpensive and motivating methodologies are required to guarantee the success of participatory monitoring activities (Danielsen et al., 2003, 2009; Bell et al., 2008). Charismatic species have been important motivators for promoting local participation (Bowen-Jones \& Entwistle, 2002; Gray \& Kalpers, 2005; Danielsen et al., 2009) and large carnivores are frequently selected as flagship species in conservation programmes, although mainly for fund-raising and educational purposes (Dalerum et al., 2008; Karanth \& Chellam, 2009). However, as these species are often perceived as a threat to human lives and livestock by local people, the utility of their image as flagship species where local support is needed has been disputed (Bowen-Jones \& Entwistle, 2002).

The jaguar Panthera onca and puma Puma concolor are the largest carnivores of the threatened Upper Paraná Atlantic Forest on the tri-national border area formed by Argentina, Brazil and Paraguay (Myers et al., 2000; Fig. 1). The jaguar is a species of particular conservation concern in this region. In Argentina it is both an Endangered species (Díaz \& Ojeda, 2000) and a National Natural Monument (Law \#25,463), and it is categorized as Vulnerable in Brazil (Chiarello et al., 2008) and as Critically Endangered in Paraguay (SEAM, 2010). Because of its large territorial demands and requirement for an adequate prey base, the jaguar has been identified as an umbrella species to design a biodiversity conservation landscape for the Upper Paraná Atlantic Forest in a tri-national conservation initiative (the Biodiversity Vision; Di Bitetti et al., 2003). In addition, two areas in this part of the Atlantic Forest were selected by a group of jaguar experts as significant areas for the conservation of the species (Jaguar Conservation Units; Sanderson et al., 2002). Therefore, studying and monitoring jaguars in the Upper Paraná Atlantic Forest were considered priorities for the species and for ecoregional conservation strategies (Sanderson et al., 2002; Di Bitetti et al., 2003).
Here we discuss the use of locally based monitoring programmes as a tool for a large-scale survey, using as a case study a project in which large carnivores were used as flagship species to promote participation. We present an updated distribution map for pumas and jaguars in the Upper Paraná Atlantic Forest resulting from a collaborative effort of local people, professionals and institutions in Argentina, Brazil and Paraguay. We also assess the effect of habitat loss on the distribution of pumas and jaguars in this Forest and the advantages of local participation and collaborative work for monitoring large carnivores at a regional scale.

\section{Study area}

We conducted this study in the core areas for long-term conservation of the Upper Paraná Atlantic Forest identified by the Biodiversity Vision (Di Bitetti et al., 2003; Fig. 1). The Upper Paraná Atlantic Forest is the largest of the 15 ecoregions that comprise the South American Atlantic Forest. It was formerly characterized by $470,000 \mathrm{~km}^{2}$ of subtropical semi-deciduous rain forests but $<8 \%$ of its original forest cover remains (Di Bitetti et al., 2003; Fig. 1). This ecoregion contains high levels of biodiversity and a diversity of human cultures (Galindo-Leal \& de Gusmão Câmara, 2003), with a high, unevenly distributed human density and diverse economic activities (Jacobsen, 2003). The Upper Paraná Atlantic Forest is distributed in eastern Paraguay, most of Misiones Province in Argentina and portions of southern Brazil (Fig. 1). The largest area of this forest is in Brazil but most large fragments $\left(>100 \mathrm{~km}^{2}\right)$ are in eastern Paraguay and the Misiones Green Corridor in Argentina, a corridor connecting two large Brazilian protected areas (Di Bitetti et al., 2003; Fig. 1).

\section{Methods}

We used two monitoring approaches to survey the puma and jaguar in the Upper Paraná Atlantic Forest. In Paraguay, Argentina and the two Brazilian protected areas connected by the Misiones Green Corridor (Fig. 1) we implemented a locally based participatory monitoring network: the Jaguar Project Monitoring Network. Additionally, we used data gathered during studies of jaguars and pumas by LC, DS, KCA and FL in the Upper ParanáPontal do Paranapanema Region, the northern portion of the Brazilian Upper Paraná Atlantic Forest (Fig. 2).

\section{The Jaguar Project Monitoring Network}

In October 2002 we held a workshop in Puerto Iguazú, Argentina, integrating researchers and stakeholders from the main institutions involved in the conservation and management of the Upper Paraná Atlantic Forest. In this 


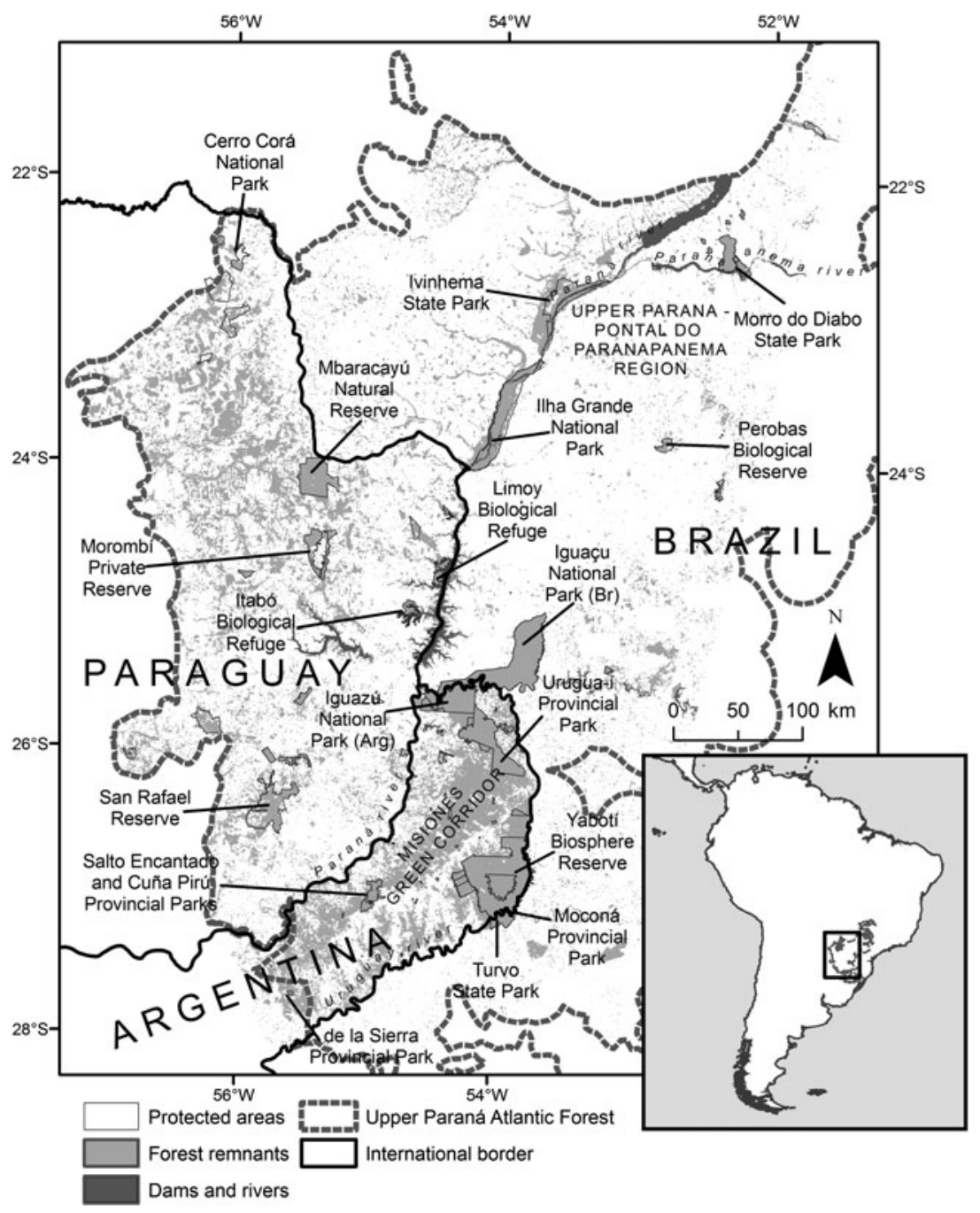

FIG. 1 Main protected areas and forest remnants in the core area of the Upper Paraná Atlantic Forest ecoregion, in which puma Puma concolor and jaguar Panthera onca presence was surveyed. The rectangle on the inset indicates the location of the main map in South America. workshop we defined the methodology and identified potential participants for constructing a network of volunteers to monitor the presence of pumas and jaguars. Between mid 2002 and 2008 we conducted 70 field training workshops on sampling techniques and data collection for people living or working in areas where large carnivores are potentially present. Initially most of the participants were park rangers and field biologists (both men and women) and members of local governmental and non-governmental institutions, who supported this initiative and provided data from protected areas and their surroundings. However, as each volunteer encouraged the integration of more people into the network, we included farmers, ranchers, forestry workers, army patrols and students, whose joint efforts allowed us to obtain information from many regions both within and beyond protected and forested areas.

We trained the participants to search for and collect track imprints and faeces of large carnivores following simple instructions: 'to collect tracks wider than $6 \mathrm{~cm}$ with the impression of the heel pad and four toes, and faecal samples $>2 \mathrm{~cm}$ diameter with prey content (hair, bones, hoofs)'. The main objective was to ensure that collaborators would collect every potential presence sign of pumas or jaguars, without the need for species-specific sign recognition in the field. Additionally, we designed a simple and rapid methodology of data collection to allow participants to incorporate the monitoring as a routine activity in their normal work without demanding extra costs and time. We provided them with a kit containing instructions and supplies for making plaster moulds of tracks and to collect and store faecal samples (Appendix 1). The kit also contained easy-to-complete cards to record data about the samples (date, collector name, site, environment). For faeces sampling, volunteers used disposable gloves and labelled paper bags. Faecal samples were dried by the volunteers inside the paper bags and stored with silica gel (Amato et al., 2006). Volunteers also recorded sightings and livestock depredation reports following pre-designed questionnaires. A coordinator (CDA) periodically visited or contacted the volunteers to compile data and provide extra kit supplies.

All participants worked for free, with the only motivation being that of collaboration for the conservation and 


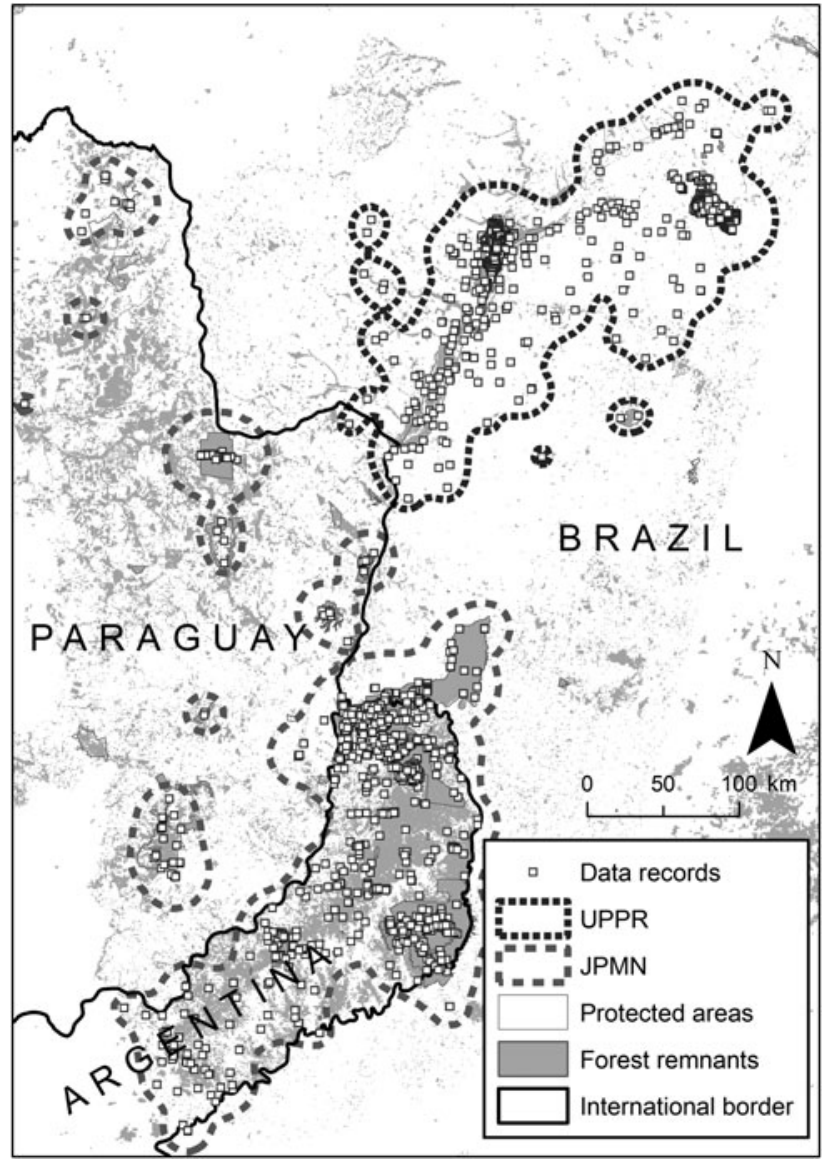

FIG. 2 Distribution of the data records $(n=2,666)$ collected by research groups in the Upper Paraná-Pontal do Paranapanema Region (UPPR) and by the Jaguar Project Monitoring Network (JPMN). Dashed lines indicate the surveyed areas estimated using the density of records (99\% kernel density estimator; see text for details).

management of both carnivore species. To help maintain motivation we prepared and distributed bulletins to inform participants about the progress of the project and provide practical information (e.g. tips for searching for presence signs). We also produced and distributed complementary materials, such as a track identification book (De Angelo et al., 2008), to help improve the quality of data collected. Additionally, we organized a tri-national workshop once per year (Appendix 2) to discuss progress and future plans with volunteers.

Although data collection was by volunteers, data selection, species identification and final analysis were by professionals, using accurate techniques and conservative criteria to avoid potential false positives of species' presence. To identify tracks we followed the protocol established by De Angelo et al. (2010), using multiple measurements combined with a discriminant function analysis (Appendix 3). We extracted a piece of the best-preserved faecal samples for DNA identification of species following methods developed by Haag et al. (2009; Appendix 3 ). We classified sightings and livestock depredation events by pumas or jaguars according to their reliability (high: direct detection by a reliable observer or with physical evidence; medium: indirect detection obtained by a reliable informer but without physical evidence; low: not able to establish reliability with confidence). We did not consider records of low reliability as presence data, and we only considered records with medium reliability if they came from regions with physical evidence of species' presence recorded in nearby areas $(<10 \mathrm{~km})$. To these data we added presence data collected by research projects (e.g. photographs from camera traps; Paviolo et al., $2008,2009)$ and information from governmental agencies (e.g. denunciations compiled and verified by the Ministry of Ecology of Misiones or the National Park Administration of Argentina).

\section{Collaborative research in the Upper Paraná-Pontal do Paranapanema Region}

Since the late 1990s various research groups have been gathering information on large predators in the Upper Paraná-Pontal do Paranapanema Region (Crawshaw, 2006). The records of jaguar and puma presence collected between 2002 and 2008 by these research groups include tracks, camera-trap photographs, records of individuals captured or killed and radio-tracking data (Cullen et al., 2005; Cullen, 2006; Abreu et al., 2009; Pró-Carnívoros, 2009; IPÊ, 2010).

\section{Data interpretation}

We determined the geographical coordinates of each record using the information provided by collectors, local maps and satellite images. Less accurate records, such as locations of low certainty, degraded faecal samples, older records and material that we could not accurately identify as being from pumas or jaguars were only used to estimate the size of the surveyed area. We used the kernel density estimator tool (Bayer, 2004) to estimate the area covered by our survey. Kernel density estimation is a non-parametric way of estimating the probability density function of a random variable, incorporating information about both spatial distribution and density, and is typically used in homerange studies (Worton, 1989).

To construct distribution maps of each species we used all presence points obtained between July 2002 and July 2008 that were confidently identified as puma or jaguar and were precisely located. We examined the locations of both species in relation to native forest cover (using forest cover estimated by supervised classification of Landsat Satellite images from 2004 by De Angelo, 2009, where native marshland habitat was included as native forest) and protected areas (using a compilation of protected areas maps for the Upper Paraná Atlantic Forest region from De Angelo, 2009). 


\section{Results}

Between 2002 and 2008 we trained c. 320 people to collect data on the presence of pumas and jaguars in the Jaguar Project Monitoring Network, representing 40 institutions (governmental, non-governmental and private) and individuals (farmers, students and others). Although most of the volunteers were park rangers $(30 \%$ including governmental and private protected areas), many collaborators were personnel or owners of private properties/companies (14\%, mainly timber and forestry companies), NGO members (12\%), students (11\%), researchers (10\%, including biologists, anthropologists and forestry engineers), local government staff (8\%), army or border security patrols (5\%), tourism guides (5\%) and farmers (4\%). Volunteer participation in the network was dynamic and not all people were active throughout the 6 years but at least 100 volunteers participated for the entire monitoring period. This collaborative effort resulted in 2,667 records (Fig. 2): 33.2\% from researchers working in the Upper Paraná-Pontal do Paranapanema Region and the remainder from the Jaguar Project Monitoring Network. The distribution of all records covered an area of $92,890 \mathrm{~km}^{2}$ (99\% kernel, $h=13,000 \mathrm{~m}$; Fig. 2 ) but most of the data were concentrated in 54,181 $\mathrm{km}^{2}$ (95\% kernel, $h=13,000$ $\mathrm{m})$. The surveyed area included $86 \%$ of the protected areas of the Upper Paraná Atlantic Forest (Appendix 4) and covered $66.2 \%$ of the remaining forest, including $68 \%$ of fragments $100-$ $1,000 \mathrm{~km}^{2}$ in size and seven of the eight largest forest fragments $>1,000 \mathrm{~km}^{2}$ (considering the Green Corridor divided by main roads into four large forest fragments; Fig. 2). Of the total data $61.2 \%$ of records were classified as reliable evidence of the presence of pumas or jaguars (Table 1).

Records of pumas were more abundant than those of the jaguar, independently of the type of record (mean $=2.25 \pm \mathrm{SE}$ 0.63 times more abundant; Table 1), with the exception of radio-tracking records that were obtained from an unbalanced number of animals (one puma versus 10 jaguars monitored; Cullen, 2006). The puma was present in most of the study area except for those areas with high human disturbance (Fig. 3). The jaguar, in contrast, was concentrated mainly in the Green Corridor of Argentina-Brazil and in the largest forest fragments in Brazil and Paraguay (Fig. 3). In Brazil we recorded jaguars only in or near the largest protected areas (Fig. 3, Appendix 4): Morro do Diabo State Park, Ivinhema State Park, Ilha Grande National Park, Perobas Biological Reserve, Iguaçu National Park and Turvo State Park. In Paraguay the largest protected areas also contained most of the country's jaguar records (Mbaracayú Natural Reserve, Morombí Private Reserve, Limoy and Itabó Biological Refuges and the southernmost record in Paraguay, in San Rafael Reserve Area for National Park, S $26^{\circ} 38^{\prime} 13.7^{\prime \prime}$ W $55^{\circ} 39^{\prime} 42.1^{\prime \prime}$; Fig. 3, Appendix 4). We recorded the southernmost jaguars in the entire Upper Paraná Atlantic Forest in Turvo State Park in Brazil (S $27^{\circ} 10^{\prime} 14.6^{\prime \prime} \mathrm{W} 53^{\circ} 51^{\prime} 4.9^{\prime \prime}$ ) and in Moconá Provincial Park in Argentina ( $\left.27^{\circ} 9^{\prime} 33.4^{\prime \prime} \mathrm{W} 53^{\circ} 53^{\prime} 28.7^{\prime \prime}\right)$. Puma records extend further south in both Argentina and Brazil (Fig. 3).

We obtained most puma (83\%) and jaguar (83\%) records in areas covered by native forest or native marshland habitat, and we confirmed puma presence in more forest fragments than jaguars (Fig. 4). Both species occurred in all the larger fragments $\left(>100 \mathrm{~km}^{2}\right)$ but $<2 \%$ of surveyed forest fragments $<10 \mathrm{~km}^{2}$ in area had evidence of the species. We detected pumas in a higher proportion of small and medium sized fragments than jaguars (Fig. 4) and the total area covered by fragments with confirmed puma presence $\left(19,266 \mathrm{~km}^{2}\right)$ was larger than the total area with confirmed presence of jaguars $\left(16,585 \mathrm{~km}^{2}\right)$. For both species these areas are $<25 \%$ of the total area surveyed.

We detected jaguars in seven large forest fragments (i.e. $>100 \mathrm{~km}^{2}$ ) outside the Jaguar Conservation Units defined for this region (Sanderson et al., 2002): Salto Encantado and Cuña Pirú provincial parks in Argentina, Morro do Diabo State Park in Brazil and five fragments in Paraguay (Fig. 3).

\section{Discussion}

\section{Partnership for regional surveys of large carnivores}

Participatory monitoring and collaboration among scientists allowed us to obtain and compile data on the distribution of

TABle 1 Confirmed records of puma Puma concolor and jaguar Panthera onca in the Upper Paraná Atlantic Forest (Fig. 1) between July 2002 and July 2008.

\begin{tabular}{|c|c|c|c|c|c|c|c|c|}
\hline \multirow[b]{2}{*}{ Species } & \multicolumn{5}{|c|}{ Jaguar Project Monitoring Network records } & \multicolumn{2}{|c|}{$\begin{array}{l}\text { Upper Paraná-Pontal do } \\
\text { Paranapanema Region records }\end{array}$} & \multirow[b]{2}{*}{ Total $^{5}$} \\
\hline & Tracks $^{1}$ & Scats $^{1}$ & Sightings & $\begin{array}{l}\text { Conflicts } \\
\text { with cattle }\end{array}$ & Others $^{2}$ & Various $^{3}$ & Telemetry locations ${ }^{4}$ & \\
\hline Puma & 236 & 25 & 50 & 19 & 136 & 168 & 18 & $634(651)$ \\
\hline Jaguar & 150 & 13 & 33 & 6 & 83 & 48 & 650 & $333(982)$ \\
\hline
\end{tabular}




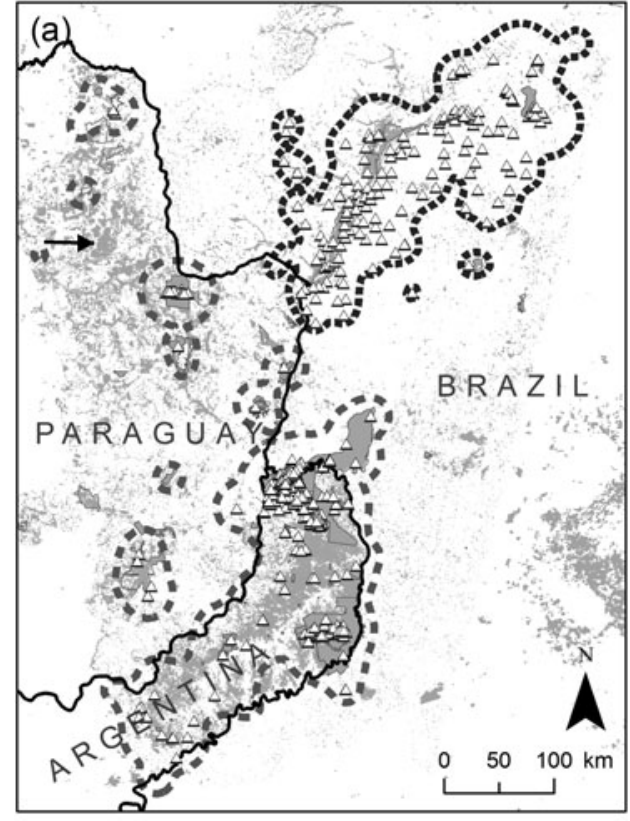

$\triangle \quad$ Puma presence

- Jaguar presence UPPR surveyed area

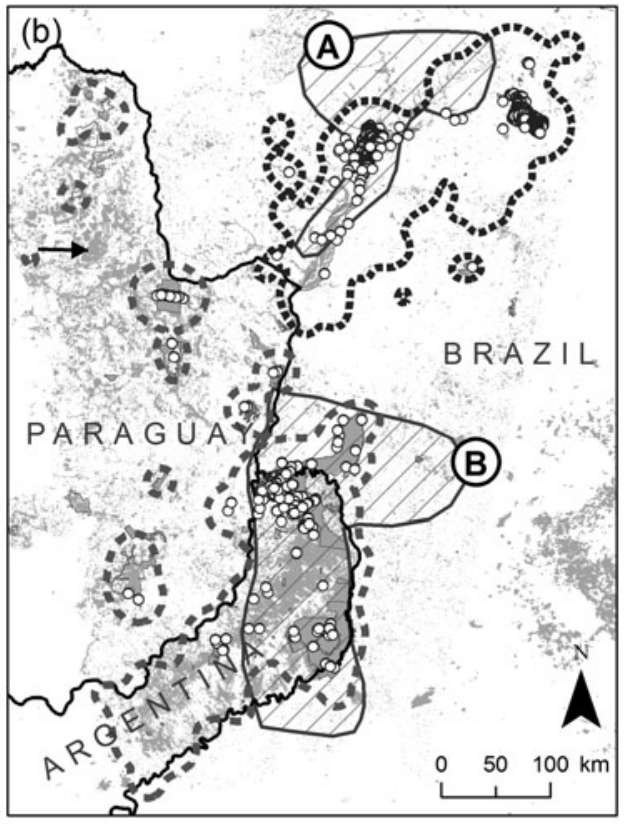

Protected areas

Forest remnants

International border

Jaguar Conservation Units

FIG. 3 (a) Puma and (b) jaguar distribution in the Upper Paraná Atlantic Forest as determined by collaborative and participatory monitoring between July 2002 and July 2008. Jaguar Conservation Units (Sanderson et al., 2002): (A) Green Corridor, (B) Upper Paraná-Pontal do Paranapanema Region. Note the numerous areas with jaguar records detected outside the Jaguar Conservation Units, particularly in Paraguay. Horizontal black arrows indicate the area of the Paraguayan Upper Paraná Atlantic Forest with large forest fragments that are poorly surveyed and where there is a high probability of the presence of both species. See caption to Fig. 2 for details of delimitation of the surveyed areas in the UPPR (Upper Paraná-Pontal do Paranapanema Region) and JPMN (Jaguar Project Monitoring Network).

two secretive species, the puma and jaguar, in most of the remnants of the Upper Paraná Atlantic Forest ecoregion. This survey had two important characteristics. One was the interaction between research groups from different countries, combining their local knowledge to understand patterns occurring at a regional scale. Partnership between researchers

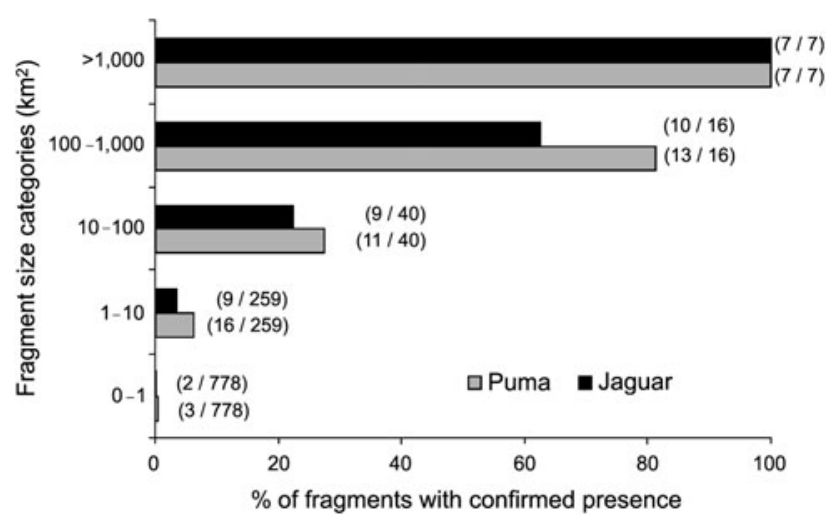

FIG. 4 Percentage of surveyed forest fragments with confirmed puma and jaguar presence, by fragment size categories (in parentheses: number of fragments with presence/total number of fragments in category included in the surveyed area). has produced useful results for jaguars and other species in other parts of the jaguar's distribution (Grigione et al., 2009) and at a continental scale (Sanderson et al., 2002).

The second characteristic was the participatory monitoring carried out by a wide network of locally based teams. Danielsen et al. (2009) suggested a typology for monitoring programmes according to the degree of local participation. Following this typology the Jaguar Project Monitoring Network could be classified as 'collaborative monitoring with external data interpretation' because local people participated not only in data collection but also in the design of the monitoring, whereas data analyses and decision making were by professionals. Danielsen et al. (2009) defined eight characteristics of the benefits and demands of participatory monitoring, and Table 2 summarizes these for the Jaguar Project Monitoring Network.

The implementation of the Jaguar Project Monitoring Network faced not only the challenges associated with the survey of a large area by people from different countries and cultures but also communication difficulties (e.g. isolated areas, difficult access by vehicle and no telephones). Nevertheless, it yielded a large amount of data and involved many local people, with no costs for participants and low 
TABLE 2 Evaluation of the Jaguar Project Monitoring Network according to the main characteristics of monitoring schemes suggested by Danielsen et al. (2009).

\begin{tabular}{|c|c|c|c|c|c|c|c|}
\hline $\begin{array}{l}\text { Cost to local } \\
\text { stakeholders }\end{array}$ & $\begin{array}{l}\text { Cost to others } \\
\text { (outsiders) }\end{array}$ & $\begin{array}{l}\text { Requirement for } \\
\text { local expertise }\end{array}$ & $\begin{array}{l}\text { Requirement for } \\
\text { external expertise }\end{array}$ & $\begin{array}{l}\text { Accuracy \& } \\
\text { precision }\end{array}$ & $\begin{array}{l}\text { Promptness of } \\
\text { decision making }\end{array}$ & $\begin{array}{l}\text { Potential for } \\
\text { enhancing local } \\
\text { stakeholder capacity }\end{array}$ & $\begin{array}{l}\text { Capacity to inform } \\
\text { national \& } \\
\text { international } \\
\text { monitoring schemes }\end{array}$ \\
\hline $\begin{array}{l}\text { None or low } \\
\text { Participants } \\
\text { selected who worked } \\
\text { or lived in or close } \\
\text { to potential puma/ } \\
\text { jaguar habitat to } \\
\text { avoid cost of } \\
\text { transportation } \\
\leq 20 \text { minutes } \\
\text { required to collect } \\
\text { samples } \\
\text { Simple \& costless } \\
\text { methods allowed } \\
\text { volunteers to } \\
\text { incorporate survey } \\
\text { in their routines } \\
\text { without extra costs } \\
\text { in time \& materials } \\
\text { (e.g. park rangers } \\
\text { collected tracks \& } \\
\text { faecal samples } \\
\text { during their patrols) }\end{array}$ & 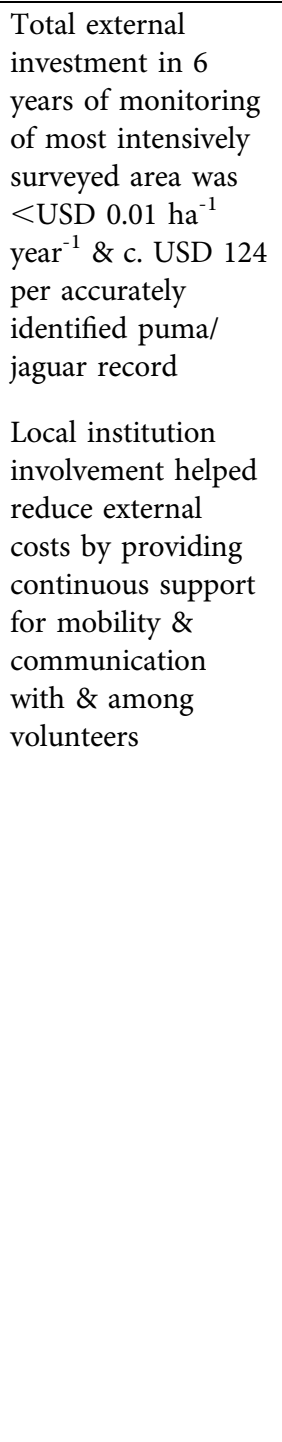 & $\begin{array}{l}\text { All participants had } \\
\text { opportunity to be } \\
\text { trained, so no } \\
\text { previous expertise } \\
\text { required } \\
\text { However, volunteers } \\
\text { with previous } \\
\text { expertise of } \\
\text { fieldwork normally } \\
\text { obtained more \& } \\
\text { better information } \\
\text { Participants' local } \\
\text { knowledge favoured } \\
\text { success in finding } \\
\text { new records }\end{array}$ & $\begin{array}{l}\text { To train volunteer } \\
\text { teams \& for network } \\
\text { coordination but } \\
\text { mainly in data } \\
\text { processing } \\
\text { Improved accuracy } \\
\text { \& precision of data } \\
\text { Catalysed transfer of } \\
\text { information to } \\
\text { national \& } \\
\text { international } \\
\text { monitoring schemes } \\
\text { Increased costs \& } \\
\text { time needed to } \\
\text { report results (i.e. } \\
\text { feedback required to } \\
\text { keep people } \\
\text { interested) } \\
\text { External expertise } \\
\text { other than field } \\
\text { biologists was } \\
\text { important for } \\
\text { communication \& } \\
\text { conservation } \\
\text { activities (e.g. } \\
\text { communication } \\
\text { campaign) }\end{array}$ & $\begin{array}{l}\text { Records were } \\
\text { accurately identified } \\
\text { to species } \\
\text { (Appendix 3) \& } \\
\text { precisely located by } \\
\text { professionals } \\
\text { Accuracy was useful } \\
\text { for distribution } \\
\text { mapping \& } \\
\text { knowledge of } \\
\text { habitat use but large } \\
\text { area sampled \& } \\
\text { difficulty of } \\
\text { quantifying } \\
\text { sampling effort } \\
\text { hindered } \\
\text { comparisons of } \\
\text { relative abundance } \\
\text { between species, } \\
\text { areas \& over time }\end{array}$ & $\begin{array}{l}\text { Facilitated prompt } \\
\text { \& coordinated } \\
\text { actions among } \\
\text { individuals \& } \\
\text { institutions for } \\
\text { mitigation of } \\
\text { human-felid } \\
\text { conflicts } \\
\text { Many volunteers } \\
\text { participated in } \\
\text { educational } \\
\text { activities (Campaña } \\
\text { Yaguareté, 2007) } \\
\text { Promoted } \\
\text { development of } \\
\text { action plans for } \\
\text { jaguars, integrating } \\
\text { institutions from } \\
\text { three countries } \\
\text { Participants had } \\
\text { direct involvement } \\
\text { in action plans for } \\
\text { large felids (e.g. } \\
\text { Chalukian, 2006), } \\
\text { which will result in } \\
\text { greater diffusion \& } \\
\text { local acceptance of } \\
\text { implementation } \\
\text { Local NGOs used } \\
\text { results to define } \\
\text { important areas of } \\
\text { forest to protect } \\
\text { under Misiones } \\
\text { Province territorial } \\
\text { plan }\end{array}$ & $\begin{array}{l}\text { Permanent contact } \\
\text { with coordinator, } \\
\text { seven informative } \\
\text { bulletins, four tri- } \\
\text { national workshops } \\
\text { \& a track } \\
\text { identification guide } \\
\text { (De Angelo et al., } \\
\text { 2008) are examples } \\
\text { of tools used for } \\
\text { enhancing } \\
\text { stakeholders' } \\
\text { capacity } \\
\text { Fostered } \\
\text { communication } \\
\text { among volunteers } \\
\text { about felid } \\
\text { conservation } \\
\text { Improved response } \\
\text { of local managers to } \\
\text { potential human- } \\
\text { felid conflicts* }\end{array}$ & $\begin{array}{l}\text { Jaguar data were } \\
\text { included in Zeller } \\
\text { (2007) } \\
\text { Felid records } \\
\text { incorporated in } \\
\text { IUCN Neotropical } \\
\text { felids' database } \\
\text { (CSG-IUCN, 2005) } \\
\text { Data are being used } \\
\text { to update } \\
\text { Argentinian } \\
\text { mammal Red List } \\
\text { Presence records of } \\
\text { white-lipped } \\
\text { peccary Tayassu } \\
\text { pecari \& tapir } \\
\text { Tapirus terrestris } \\
\text { were requested of } \\
\text { volunteers \& } \\
\text { incorporated in } \\
\text { continental surveys } \\
\text { by the Wildlife } \\
\text { Conservation } \\
\text { Society \& IUCN } \\
\text { specialists groups }\end{array}$ \\
\hline
\end{tabular}

${ }^{*}$ Some examples of combined management interventions with the involvement of different parts of the Jaguar Project Monitoring Network, as communicated in the local, national and international press, can be found in Territorio Digital $(2004,2008)$ Mullen (2006), La Nación (2007) and Misiones Online (2009) 
costs for external institutions (Table 2). Considering Danielsen et al.'s (2005) summary, external cost investment in the Jaguar Project Monitoring Network ( $<$ USD $0.01 \mathrm{ha}^{-1}$ year $\left.^{-1}\right)$ is among the lowest costs estimated for similar participatory monitoring programmes (USD 0.01-0.13 ha $\mathrm{ha}^{-1}$ year $^{-1}$ ) and much lower than the cost estimated for professional surveys (c. USD $3.6 \mathrm{ha}^{-1}$ year $^{-1}$; Danielsen et al., 2009; Table 2). Although professional surveys (e.g. with camera traps) may allow more detailed information to be obtained (e.g. density estimates), their application at broader scales may not only be more expensive but also practically infeasible or unsustainable for long periods of time. Locally based surveys have the advantage of being able to maintain permanent long-term monitoring in many areas simultaneously, which is the best survey technique for obtaining data in areas where large carnivores live at extremely low densities (Karanth \& Nichols, 2002).

The low cost associated with the Jaguar Project Monitoring Network was not only the result of a simple affordable methodology but also of the commitment of participants and the support received from many local governmental and non-governmental institutions that allowed the monitoring to be incorporated in the routine activities of their personnel. Volunteers showed great interest and enthusiasm for seeking evidence of large predators, and the subsequent recognition for their work from the coordinator and other volunteers promoted increased efforts. Enthusiasm, credit and desire for learning have been recognized as important drivers for maintaining interest amongst volunteers (Danielsen et al., 2007; Bell et al., 2008). However, the powerful image of the species monitored was essential to enthuse and involve local people and institutions in the Network, and both species, but mainly the jaguar, were important motivators for people and institutions, and also contributed to the growth of the Network (e.g. people who spontaneously offered to join the Network because of their interest in jaguars). This demonstrated that with adequate motivation and methods, volunteer work is possible in developing countries even though volunteering is not as culturally common as in developed countries (Danielsen et al., 2003, 2009; Bell et al., 2008).

Comparable experiences of motivation were reported by Poulsen \& Luanglath (2005) in participatory biodiversity monitoring in Laos and by park rangers monitoring gorilla Gorilla beringei beringei populations in Rwanda, Uganda and the Democratic Republic of Congo (Gray \& Kalpers, 2005). As in the Jaguar Project Monitoring Network, gorillas were used as flagship species to help maintain participants' interest and motivation. Through the Network we showed that, despite their conflicting image for cattle ranchers and some local people (Conforti \& Azevedo, 2003), large carnivores may have special value as flagship species when they have positive associations for the selected focal audience (Bowen-Jones \& Entwistle, 2002; Dalerum et al., 2008). Although most participants in the Network had a positive relationship with jaguars some ranchers, who may be expected to have a negative relationship with the species, joined the network because of their concern for the conservation of felids. Although we did not put much effort into the recruitment of ranchers as volunteers, we believe that rancher-based local monitoring with adequate advice from professionals (i.e. agronomists, sociologists) and government involvement may prove a useful tool not only in monitoring predators but also in reducing humanpredator conflicts.

In spite of low costs and strong local support, the Jaguar Project Monitoring Network demanded large and permanent coordination efforts (e.g. personal contact with volunteers and communication activities). Because the coordinator (CDA) could not commit himself to this endeavour for $>_{5}$ years and because funds were not secured for the long-term (the project was conceived and funded mostly by NGOs), the continuity of the coordination of the Network and the monitoring was not ensured, and finished in 2008. Discontinuous funding is a common problem for sustaining monitoring over long periods of time (Brashares \& Sam, 2005; Poulsen \& Luanglath, 2005). The involvement of local institutions is essential to guarantee monitoring continuity over time without permanent external funds, enhancing the important role that involvement of local institutions has for participatory monitoring (Danielsen et al., 2005; Gray \& Kalpers, 2005; Poulsen \& Luanglath, 2005).

Similar surveys have frequently left identification of records in charge of local people (e.g. using interviews; McNab \& Polisar, 2002; Altrichter et al., 2006). However, jaguars have a conspicuous cultural value in local communities in the Upper Paraná Atlantic Forest (Conforti \& Azevedo, 2003) and their strong image and the similarity of their signs with those of pumas may cause a bias towards overrating jaguar presence and to misidentify the signs of pumas as belonging to jaguars, as occurs with other large carnivores (Lynam, 2002). The use of physical evidence and precise identification methods reduces this problem but demands more professional involvement. However, professional participation may not only increase accuracy and precision but also result in a wider use of the data gathered (Table 2).

There are two other important aspects of local participation in monitoring biodiversity: its implications for promptness of decision making and its potential for enhancing local stakeholder capacity (Danielsen et al., 2009). The Jaguar Project Monitoring Network had significant outcomes in both aspects (Table 2) but, most importantly, it promoted collaborative work in conservation and management of large felids at a regional scale through the involvement and training of people from different institutions, professions and countries. Since the creation of the Network complaints of potential conflicts 
(e.g. felid sightings in populated areas, cattle killed) are communicated not only to local authorities but also to Network members, favouring the intervention of many institutions. As a result, a protocol of action is being drawn up and will be implemented through the bi-national action plan for jaguars in the Argentina-Brazil Green Corridor. This plan incorporates not only this protocol but also the information and ideas collected in the various different meetings in which the Network volunteers participated (Table 2). Additionally, the information gathered proved useful for other regional conservation initiatives: an action plan for jaguars in Paraguay is in the initial stages and, in the Upper Paraná-Pontal do Paranapanema Region, a jaguar action plan is being developed (Table 2).

\section{Jaguars and pumas in the Upper Paraná Atlantic Forest}

Although many human pressures can affect the persistence of species, habitat destruction has particularly harmful effects on large carnivores that require extensive territories (Karanth \& Chellam, 2009). Pumas and jaguars in the Upper Paraná Atlantic Forest have been seriously affected by forest loss and fragmentation. A clear indication of this is that these species are almost exclusively associated with medium and large fragments of native forest in a region where most of the landscape has been transformed to anthropogenic land uses (Figs $3 \& 4$ ).

The puma still occupies most of its continental distribution but has disappeared or became rare in those areas with the highest human pressures (Sunquist \& Sunquist, 2002). In the Upper Paraná Atlantic Forest pumas are present in a significant proportion of the forest remnants, including many areas where the jaguar was not recorded (Fig. 3). However, fragments with puma presence represent $<25 \%$ of the surveyed area and we did not find evidence of pumas in areas with intensive agriculture or with high human presence (Figs $3 \& 4$ ). Therefore, although pumas have apparently suffered less range contraction than jaguars, habitat loss and fragmentation along with the impacts of intense logging and poaching have resulted in the decrease of puma populations in the Upper Paraná Atlantic Forest (Paviolo et al., 2009).

The continental distribution of the jaguar has contracted severely (Sanderson et al., 2002; Zeller, 2007). In Brazil, where c. $50 \%$ of the continental range of the jaguar persists, habitat loss is the most important cause of jaguar decline (Tôrres et al., 2008). In the Brazilian Atlantic Forest habitat destruction has been high (de Gusmão Câmara, 2003), and Mazzolli (2009) described a south-to-north reduction of jaguar distribution in coastal Atlantic Forest caused by habitat fragmentation and poaching of jaguars. In the Upper Paraná Atlantic Forest of Brazil the main forest fragments are within protected areas, and it is only in these areas where the jaguar persists (Fig. 3, Appendix 4). Habitat loss is probably the main reason for jaguar range contraction in the Brazilian Upper Paraná Atlantic Forest but poaching of jaguars and their prey is also affecting jaguars in this region (Conforti \& Azevedo, 2003; Cullen et al., 2005; Abreu et al., 2009). Reducing these threats is essential for jaguar survival (Cullen et al., 2005) but habitat recovery and connectivity are necessary to increase dispersal between populations and to reduce the genetic loss that fragmentation is producing in this region (Haag et al., 2010).

In Paraguay we also obtained most jaguar records from within protected areas that harbour the most extensive forest fragments. The largest jaguar population in eastern Paraguay is probably located in Mbaracayú Nature Reserve and surrounding areas (Fig. 3). However, important forest remnants not surveyed by the Jaguar Project Monitoring Network persist in Canindeyú, Amambay and San Pedro departments, where we obtained informal data of puma and jaguar presence (Fig. 3). These areas could be important for maintenance of the connectivity among jaguar populations of the Atlantic Forest and chacoan and cerrado jaguar populations in western Paraguay. Although 30 years ago the Paraguayan Upper Paraná Atlantic Forest was a vast continuous forest it has suffered recent and rapid conversion (Huang et al., 2007). Many of the areas with jaguar presence in Paraguay correspond with recently reduced and isolated fragments, and many of these isolated and small jaguar populations will probably disappear in the short-term. Although other pressures exist, habitat loss and fragmentation are also the main threats to the jaguar in eastern Paraguay.

In the Argentinian Upper Paraná Atlantic Forest jaguar records were concentrated in the Green Corridor (Fig. 4) where a large and continuous corridor of forest remains. Argentina has had the highest national rate of jaguar range contraction (Di Bitetti et al., 2006), occurring in a south-tonorth pattern. The last records of jaguars in Corrientes Province (south of Misiones province) date from the $1970 \mathrm{~s}$ (Giraudo \& Povedano, 2003) and the latest reliable records we obtained for southern Misiones date from the early 1990s. Since the mid 1990s the southernmost jaguar records in Misiones are in the central and eastern parts of the province (Giraudo \& Povedano, 2003) where jaguars were detected by the Jaguar Project Monitoring Network (Fig. 3). These areas, and Turvo State Park in Brazil, are currently the southernmost limit of jaguar distribution (Sanderson et al., 2002; Zeller, 2007). Although habitat loss is affecting jaguar range in the Argentinian Upper Paraná Atlantic Forest, many areas with large forest fragments outside the Green Corridor harbour pumas but not jaguars (Fig. 3), suggesting that other factors have caused the disappearance of jaguars in these areas. A vast extent of the Argentinian Forest has been heavily logged and there is high poaching pressure on the jaguar and its prey, probably the main causes of a recent decline of jaguars in the Green Corridor 
(Paviolo et al., 2008). Although maintenance of forest cover is essential, reducing other human threats is critical for survival of the jaguar in this area (Paviolo et al., 2008).

The monitoring programme allowed us to detect both species in areas where there was no information available or where they were considered rare or locally extinct. The data have contributed not only to a more complete understanding of the effect of habitat loss on both species (e.g. through habitat suitability modelling, De Angelo et al., 2011, and genetic studies, Haag et al., 2010) but is also helping in conservation and management actions (Table 2). An updated and more detailed definition of the Jaguar Conservation Units (Fig. 3) will help to improve local, regional and continental conservation plans (Rabinowitz \& Zeller, 2010). A re-evaluation of the conservation landscape designed by Di Bitetti et al. (2003) for the Upper Paraná Atlantic Forest is in progress, and this is another important outcome for which the data collected in this participatory survey were utilized.

\section{Acknowledgements}

We are very grateful to all the volunteers, collaborators and institutions who participated in the Jaguar Project Monitoring Network, particularly to C. Boiero, P. Crawshaw Jr, Y. Di Blanco, E. Eizirik, A. García, M. Gómez, E. Krauczuk, M. Jaramillo, R. Melzew, E. Pizzio, G. Placci, M. Rinas, A. Rodrigues, K. Schiaffino, S. Welcz, the National Parks Administration (Argentina), the Ministry of Ecology of Misiones Province (Argentina), Itaipu Binacional (Paraguay/Brazil), Pro-Cosara (Paraguay), Instituto de Derecho y Economía Ambiental (Paraguay), and our hosting institutions. Financial support was provided by the National Research Council of Argentina (CONICET), Fundación Vida Silvestre Argentina, WWF-USA, WWF-International, WWF-Switzerland, WWF Education for Nature Program, Species Action Fund (WWF-US) and Lincoln Park Zoo.

\section{References}

Abreu, K.C., Mellek, D.M., Lima, F. \& Cullen, Jr, L. (2009) O envolvimento comunitário na intervenção da predação de rebanhos domésticos no Alto Rio Paraná. Caderno do Grupo de Educação e Extensão Socioambiental do Instituto de Pesquisas Ecológicas, 1, 25-38.

Altrichter, M., Boaglio, G. \& Perovic, P. (2006) The decline of jaguars Panthera onca in the Argentine Chaco. Oryx, 40, 302-309.

Amato, G., Rabinowitz, S. \& Hunter, L. (2006) A Field Manual for the Collection, Storage, and Transportation of Biomaterials for Genetic Studies on Felids. American Museum of Natural HistoryWildlife Conservation Society, New York, USA.

B AYer, H.L. (2004) Hawth's Analysis Tools for ArcGIS. Http:// www.spatialecology.com/htools [accessed 10 February 2009].

Bell, S., Marzano, M., Cent, J., Kobierska, H., Podjed, D., VAndzinskaite, D. et al. (2008) What counts? Volunteers and their organisations in the recording and monitoring of biodiversity. Biodiversity and Conservation, 17, 3443-3454.

Bowen-Jones, E. \& Entwistle, A. (2002) Identifying appropriate flagship species: the importance of culture and local contexts. Oryx, 36, 189-195.

Brashares, J.S. \& SAM, M.K. (2005) How much is enough? Estimating the minimum sampling required for effective monitoring of African reserves. Biodiversity and Conservation, 14, 2709-2722.

Campaña Yaguareté (2007) Campaña Yaguareté, dejá tu huella. Fundación Vida Silvestre Argentina, Administración de Parques Nacionales, Ministerio de Ecología, Recursos Naturales Renovables y Turismo de Misiones. Puerto Iguazú, Argentina. Http://www.yaguarete.net [accessed 16 February 2011].

Carroll, C. \& Miquelle, D.G. (2006) Spatial viability analysis of Amur tiger Panthera tigris altaica in the Russian Far East: the role of protected areas and landscape matrix in population persistence. Journal of Applied Ecology, 43, 1056-1068.

Chalukian, S. (2006) Informe del 2do Taller Monumento Natural Nacional Yaguareté y 6to Taller Monumento Natural Provincial Yaguareté en Misiones. Dirección de Fauna Silvestre, Administración de Parques Nacionales, Ministerio de Ecología, Recursos Naturales Renovables y Turismo de Misiones, Asociación Civil Centro de Investigaciones del Bosque Atlántico, and Fundación Vida Silvestre Argentina, Posadas, Misiones, Argentina.

Chiarello, A.G., Aguiar, L.M. De S., Cerqueira, R., Melo, F.R. De, Rodrigues, F.H.G. \& Silva, V.M.F. De (2008) Mamíferos ameaçados de extinção no Brasil. In Livro vermelho da fauna brasileira ameaçada de extinção (eds A.B.M. Machado, G.M. Drummond \& A.P. Paglia), pp. 681-874. Departamento de Conservação da Biodiversidade, Secretaria de Biodiversidade e Florestas, Ministério do Meio Ambiente do Brasil, Brasilia, Brazil.

Conforti, V.A. \& Azevedo, F.C.C. (2003) Local perceptions of jaguars (Panthera onca) and pumas (Puma concolor) in the Iguaçu National Park area, south Brazil. Biological Conservation, 111, 215-221.

Crawshaw, JR, P.G. (2006) The history of carnivore research in Brazil. In Manejo e conservaçao de carnívoros neotropicais (eds R.G. Morato, F.H.G. Rodrigues, E. Eizirik, P.R. Mangini, F.C.C. Azevedo \& J. Marinho, Jr), pp. 17-37. IBAMA-CENAPMinisterio do Meio Ambiente, Saõ Paulo, Brazil.

CSG-IUCN (CAT Specialist Group-IUCN) (2005) Status \& Conservation Needs of the Neotropical Felids, International Conference \& Workshop. IUCN Cat Specialist Group. Saõ Francisco de Paula, Brazil.

Cullen, JR, L. (2006) Jaguars as Landscape Detectives for the Conservation of Atlantic Forests in Brazil. University of Kent, Canterbury, USA.

Cullen, Jr, L., Abreu, K.C., Sana, D. \& Nava, A.F.D. (2005) Jaguars as landscape detectives for the upper Paraná River corridor, Brazil. Natureza e Conservação, 3, 43-58.

Dalerum, F., Somers, M., Kunkel, K. \& Cameron, E. (2008) The potential for large carnivores to act as biodiversity surrogates in southern Africa. Biodiversity and Conservation, 17, 2939-2949.

Danielsen, F., Burgess, N. \& Balmford, A. (2005) Monitoring matters: examining the potential of locally-based approaches. Biodiversity and Conservation, 14, 2507-2542.

Danielsen, F., Burgess, N.D., Balmford, A., Donald, P.F., Funder, M., Jones, J.P.G. et al. (2009) Local participation in natural resource monitoring: a characterization of approaches. Conservation Biology, 23, 31-42.

Danielsen, F., Mendoza, M.M., Tagtag, A., Alviola, P., Balete, D.S., Enghoff, M. et al. (2003) Biodiversity monitoring in developing countries: what are we trying to achieve? Oryx, 37, 407-409. 
Danielsen, F., Mendoza, M.M., Tagtag, A., Alviola, P.A., B ALETE, D.S., JENSEN, A.E. et al. (2007) Increasing conservation management action by involving local people in natural resource monitoring. Ambio, 36, 566-570.

De Angelo, C. (2009) El paisaje del Bosque Atlántico del Alto Paraná y sus efectos sobre la distribución y estructura poblacional del jaguar (Panthera onca) y el puma (Puma concolor). $\mathrm{PhD}$ thesis, Universidad de Buenos Aires, Buenos Aires, Argentina.

De Angelo, C., Paviolo, A. \& Di Bitetti, M. (2010) Traditional versus multivariate methods for identifying jaguar, puma, and large canid tracks. Journal of Wildlife Management, 74, 1141-1153.

De Angelo, C., Paviolo, A. \& Di Bitetti, M. (2011) Differential impact of landscape transformation on pumas (Puma concolor) and jaguars (Panthera onca) in the Upper Paraná Atlantic Forest. Diversity and Distributions, 17, 422-436.

De Angelo, C., Paviolo, A., Di Blanco, Y. \& Di Bitetti, M. (2008) Guía de huellas de los mamíferos de Misiones y otras áreas del Subtrópico de Argentina. Ediciones del Subtrópico, San Miguel de Tucumán, Argentina.

de Gusmão CÂmara, I. (2003) Brief history of conservation in the Atlantic Forest. In Atlantic Forest of South America: Biodiversity Status, Threats, and Outlook (eds C. Galindo-Leal \& I. de Gusmão Câmara), pp. 31-42. Island Press, Washington, DC, USA.

Díaz, G.B. \& OJEDA, R.A. (200o) Libro rojo de los mamíferos amenazados de Argentina. Sociedad Argentina para el estudio de los Mamíferos, Buenos Aires, Argentina.

Di Bitetti, M.S., De Angelo, C., Paviolo, A., Schiafino, K. \& Perovic, P. (2006) Monumento Natural Nacional en peligro: el desafío de conservar al yaguareté en la Argentina. In La Situación Ambiental Argentina 2005 (eds A. Brown, U. Martinez Ortiz, M. Acerbi \& J. Corcuera), pp. 420-431. Fundación Vida Silvestre Argentina, Buenos Aires, Argentina.

Di Bitetti, M.S., Placci, G. \& Dietz, L.A. (2003) A Biodiversity Vision for the Upper Paraná Atlantic Forest Eco-region: Designing a Biodiversity Conservation Landscape and Setting Priorities for Conservation Action. World Wildlife Fund, Washington, DC, USA.

Galindo-Leal, C. \& de Gusmão CÂmara, I. (eds) (2003) Atlantic Forest of South America: Biodiversity Status, Threats, and Outlook. Island Press, Washington, DC, USA.

Giraudo, A.R. \& Povedano, H. (2003) Threats of extinction to flagship species in the Interior Atlantic Forest. In Atlantic Forest of South America: Biodiversity Status, Threats and Outlook (eds C. Galindo-Leal \& I. de Gusmão Câmara), pp. 191-193. Island Press, Washington, DC, USA.

Gray, M. \& Kalpers, J. (2005) Ranger based monitoring in the Virunga-Bwindi region of East-Central Africa: a simple data collection tool for park management. Biodiversity and Conservation, 14, 2723-2741.

Grigione, M.M., Menke, K., López-González, C., List, R., Banda, A., Carrera, J. et al. (2009) Identifying potential conservation areas for felids in the USA and Mexico: integrating reliable knowledge across an international border. Oryx, 43, 78-86.

Haag, T., Santos, A.S., De Angelo, C., Srbek-Araujo, A.C., Sana, D., Morato, R.G. et al. (2009) Development and testing of an optimized method for DNA-based identification of jaguar (Panthera onca) and puma (Puma concolor) faecal samples for use in ecological and genetic studies. Genetica, 136, 505-512.

Haag, T., Santos, A.S., Sana, D., Morato, R.G., Cullen, JR, L., Crawshaw, JR, P.G. et al. (2010) The effect of habitat fragmentation on the genetic structure of a top predator: loss of diversity and high differentiation among remnant populations of Atlantic Forest jaguars (Panthera onca). Molecular Ecology, 19, 4906-4921.
Huang, C., Kim, S., Altstat t, A., Townshend, J.R.G., Davis, P. \& SoNG, K. (2007) Rapid loss of Paraguay's Atlantic Forest between 1970 s and 2000 and the status of protected areas. Remote Sensing of Environment, 106, 460-466.

IPÊ (2010) Detetives Ecológicos. Insitituto de Pesquisas Ecológicas, Nazaré Paulista, Brazil. Http://www.ipe.org.br/pontal/detetivesecologicos [accessed 16 February 2011].

Jacobsen, T.R. (2003) Populating the environment: human growth, density, and migration in the Atlantic Forest. In The Atlantic Forest of South America: Biodiversity Status, Threats, and Outlook (eds C. Galindo-Leal \& I. de Gusmão Câmara), pp. 426-435. Island Press, Washington, DC, USA.

Karanth, K.U. \& Chellam, R. (2009) Carnivore conservation at the crossroads. Oryx, 43, 1-2.

Karanth, K.U. \& Nichols, J.D. (eds) (2002) Monitoring Tigers and Their Prey. A Manual for Researchers, Managers and Conservationists in Tropical Asia. Centre for Wildlife Studies, Bangalore, India.

LA NACIÓN (2007) Capturan y reubican a un yaguareté. Diario La Nación, Sociedad, 29 September 2007. Buenos Aires, Argentina. Http://www.lanacion.com.ar/nota.asp?nota_id $=948488$ \&high $=$ yaguaret\%E9 [accessed 16 February 2011].

Lynam, A.J. (2002) Métodos de trabajo de campo para definir y proteger poblaciones de gatos grandes: los tigres indochinos como un estudio de caso. In El jaguar en el nuevo milenio (eds R.A. Medellín, C. Equihua, C.L. Chetkiewicz, P.G. Crawshaw, Jr, A. Rabinowitz, K.H. Redford et al.), pp. 55-71. Fondo de Cultura Económica-Wildlife Conservation Society-UNAM, Mexico, DF, Mexico.

Mazzolli, M. (2009) Loss of historical range of jaguars in southern Brazil. Biodiversity and Conservation, 18, 1715-1717.

McNab, B.R. \& Polisar, J. (2002) Una metodología participativa para una estimación rápida de la distribución del jaguar en Guatemala. In El Jaguar en el Nuevo Milenio (eds R.A. Medellín, C. Equihua, C.L. Chetkiewicz, P.G. Crawshaw, Jr, A. Rabinowitz, K.H. Redford et al.), pp. 73-90. Fondo de Cultura EconómicaWildlife Conservation Society-UNAM, Mexico, DF, Mexico.

Misiones Online (2009) El cuero de yaguareté decomisado en Iguazú había sido fotografiado durante 2006. Misiones Online, 30 January 2009. Posadas, Argentina. Http://www.misionesonline.net/noticias/30/01/2009/el-cuero-de-yaguarete-decomisadoen-iguazu-habia-sido-fotografiado-durante-2006 [accessed 16 February 2011].

Mullen, W. (2006) Cagey cats finally may be captured-at least on camera. Chicago Tribune, 9 February 2006. Chicago, USA. Http:// articles.chicagotribune.com/2006-02-09/news/0602090272_1_ jaguar-lincoln-park-zoo-big-cats [accessed 16 February 2011].

Myers, N., Mittermeier, R.A., Mittermeier, C.G., Da FonsecA, G.A.B. \& Kent, J. (2000) Biodiversity hotspots for conservation priorities. Nature, 403, 853-858.

Noss, R.F., Quigley, H.B., Hornocker, M.G., Merrill, T. \& PAQuet, P.C. (1996) Conservation biology and carnivore conservation in the Rocky Mountains. Conservation Biology, 10, 949-963.

Paviolo, A., De Angelo, C.D., Di Blanco, Y.E. \& Di Bitetti, M.S. (2008) Jaguar Panthera onca population decline in the Upper Paraná Atlantic Forest of Argentina and Brazil. Oryx, 42, 554-561.

Paviolo, A., Di Blanco, Y., De Angelo, C. \& Di Bitetti, M. (2009) Protection affects puma abundance and activity patterns in the Atlantic Forest. Journal of Mammalogy, 90, 926-934.

Paviolo, A., De Angelo, C., Di Blanco, Y., Ferrari, C., Di Bitetti, M.S., Kasper, C.B. et al. (2006) The need for transboundary efforts to preserve the southernmost jaguar population in the world. Cat News, 45, 12-14. 
Poulsen, M.K. \& Luanglath, K. (2005) Projects come, projects go: lessons from participatory monitoring in southern Laos. Biodiversity and Conservation, 14, 2591-2610.

Pró-Carnívoros (2009) Ecologia e Conservação de grandes felinos do Alto Rio Paraná-MS/SP. Pró-Carnívoros, Atibaia, Brazil. Http:// www.procarnivoros.org.br/2009/projeto1.asp?projeto $=38$ [accessed 16 February 2011].

Rabinowitz, A. \& Zeller, K.A. (2010) A range-wide model of landscape connectivity and conservation for the jaguar, Panthera onca. Biological Conservation, 143, 939-945.

Sanderson, E.W., Redford, K.H., Chetkiewicz, C.L.B., Medellin, R.A., Rabinowitz, A.R., Robinson, J.G. \& Taber, A.B. (2002) Planning to save a species: the jaguar as a model. Conservation Biology, 16, 58-72.

SEAM (2010) Jaguarete, Jaguar o Tigre Americano. Secretaría del Ambiente de Paraguay, Asunción, Paraguay. Http://www.seam. gov.py/especies-amenazadas-de-extincion/mamiferos/yaguareteo-tigre-americano.html [accessed 16 February 2011].

Sunquist, M. \& Sunquist, F. (2002) Wild Cats of the World. University of Chicago Press, Chicago, USA.

Territorio Digital (2004) Sacrificaron a tiros a un yaguareté que había atacado a un vecino. Territorio Digital, Ecología, 13 May 2004. Posadas, Misiones, Argentina. Http://www.territoriodigital.com/nota.aspx? $\mathrm{c}=0605855953180729 \& \mathrm{r}=1$ [accessed 16 February 2011].

Territorio Digital (2008) Monitorean sobre la selva a un yaguareté. Territorio Digital, Ecología, 29 May 2008. Posadas, Misiones, Argentina. Http://www.territoriodigital.com/nota.aspx?c= $4808814950268493 \& \mathrm{r}=1$ [accessed 16 February 2011].

Tôrres, N.M., De Marco, Jr, P., Diniz Filho, J.A.F. \& Silveira, L. (2008) Jaguar distribution in Brazil: past, present and future. Cat News, Special Issue 4, 4-8.

Wemmer, C., Kunz, T.H., Lundie-Jenkins, G. \& McShea, W.J. (1996) Mammalian sign. In Measuring and Monitoring Biological
Diversity-Standard Methods for Mammals (eds D.E. Wilson, F.R. Cole, J.D. Nichols, R. Rudran \& M.S. Foster), pp. 157-176. Smithsonian Institution Press, Washington, DC, USA.

Woodroffe, R. \& Ginsberg, J.R. (1998) Edge effects and the extinction of populations inside protected areas. Science, 280, $2126-2128$.

Worton, B.J. (1989) Kernel methods for estimating the utilization distribution in home-range studies. Ecology, 70, 164-168.

Zeller, K. (2007) Jaguars in the New Millennium Data Set Update: The State of the Jaguar in 2006. Wildlife Conservation Society's Jaguar Conservation Program, Takoma Park, USA.

\section{Appendices}

The appendices for this article are available online at http:// journals.cambridge.org

\section{Biographical sketches}

The authors work on various aspects of the ecology, genetics, conservation and management of biodiversity in Argentina, Brazil and Paraguay. As scientists, managers or conservationists the authors belong to a variety of governmental and non-governmental institutions but share a common interest in biodiversity conservation, and are particularly concerned about the conservation of pumas and jaguars as keystone and umbrella species in the Atlantic Forest. In this study they combined their efforts and expertise, taking advantage of their diverse capabilities to assess the population status of large felids from a regional perspective and undertake coordinated conservation actions. 